\title{
NOTES
}

\section{BURROWING OWLS PRODUCE SECOND BROOD IN MOUNTAIN VIEW, CALIFORNIA}

PHILIP G. HIGGINS, Talon Ecological Research Group, 105 N. $1^{\text {st }}$ Street \#424,

San Jose, California 95103; philip.higgins@talonecological.org

DEBRA CHROMCZAK, 4569 Branciforte Drive, Santa Cruz, California 95065; DChromcz@pacbell.net

RYAN A. PHILLIPS, Talon Ecological Research Group, 105 N. $1^{\text {st }}$ Street \#424, San Jose, California 95103; ryan.phillips@talonecological.org

Western Burrowing Owls (Athene cunicularia hypugaea) are capable of laying up to 12 eggs in a single clutch (Haug et al. 1993). If the first nest attempted in a season fails, the female often lays a replacement clutch (Thomsen 1971, Wedgewood 1976). But rearing of a second brood after the fledging of a first brood (double brooding) is uncommon in this species (Millsap and Bear 1990, Gervais and Rosenberg 1999). In 2020, after 23 years of continuous monitoring of Burrowing Owls nesting around the southern periphery of San Francisco Bay at Shoreline Regional Wildlife Area in Mountain View, Santa Clara County, California, we confirmed double brooding for the first time. The Burrowing Owls were being supplementally fed with mice to assess whether such feeding during the breeding season increases their reproductive success; this experiment may have resulted in the double brood. However, this instance of double brooding occurred three years after supplemental feeding commenced.

Shoreline Regional Wildlife Area is a closed landfill, posing management issues for a species such as the Burrowing Owl because the decomposition of the trash causes the ground to subside. The subsequent repairs of the cap of clay sealing the landfill destroy California Ground Squirrel (Otospermophilus beecheyi) burrows that are critical for the owls' survival (Haug et al. 1993). To mitigate for the continuing loss of squirrel burrows, we install artificial burrows consisting of an irrigation valve box for the nest chamber and a 6 -foot-long flexible drainage pipe to simulate the burrow tunnel. These artificial burrows have proven very successful. During the 2020 breeding season, six of the eight breeding pairs at Shoreline successfully nested in artificial burrows.

The pair of Burrowing Owls that double brooded in 2020 used two different nests. Every breeding season, we have observed some pairs at our study sites abandon a nest after 28-30 days of an unsuccessful attempt, then move to a new nest burrow, renest, and successfully produce nestlings. From our field observations of nesting materials and decoration at the burrow entrance, food delivery by the male to the female, and the female remaining underground for several weeks, we presumed the female in these failed first nests was incubating eggs.

In 2017, we started a supplemental-feeding study in which we fed Burrowing Owl pairs at two of our four study sites, to allow for comparison of the success of supplementally fed pairs and unfed pairs. The sites other than Shoreline Regional Wildlife Area are the Ames Research Center at Moffett Field, the San Jose-Santa Clara regional wastewater facility in Alviso, and the Warm Springs Unit of Don Edwards San Francisco Bay National Wildlife Refuge, all around the south end of San Francisco Bay (Table 1). The Burrowing Owl pairs were fed with fourteen dead mice, over two feedings per week, for the duration of the breeding season, April to August of each year. On the basis of the initial success of the supplemental-feeding study (100\% nest success and largest number of chicks fledged since 2004) and the Burrowing Owl's continuing decline in the region, we decided to supplementally 
TABLE 1 Numbers of Burrowing Owls Monitored around South San Francisco Bay

\begin{tabular}{|c|c|c|c|c|c|}
\hline Site & $\begin{array}{l}\text { Study } \\
\text { period }\end{array}$ & $\begin{array}{l}\text { Total number } \\
\text { of adults }\end{array}$ & $\begin{array}{l}\text { Total number } \\
\text { of breeding } \\
\text { females/pairs }\end{array}$ & $\begin{array}{l}\text { Minimum } \\
\text { number of } \\
\text { breeding } \\
\text { females/pairs } \\
\text { in a year }\end{array}$ & $\begin{array}{l}\text { Maximum } \\
\text { number of } \\
\text { breeding } \\
\text { females/pairs } \\
\text { in a year }\end{array}$ \\
\hline $\begin{array}{l}\text { NASA Ames Research } \\
\text { Center at Moffett } \\
\text { Field }\end{array}$ & $\begin{array}{c}1998-2020 \\
(23 \text { seasons })\end{array}$ & 679 & 323 & $2(2020)$ & 30 (1999) \\
\hline $\begin{array}{l}\text { San Jose-Santa Clara } \\
\text { Regional Wastewater } \\
\text { Facility bufferlands in } \\
\text { Alviso }\end{array}$ & $\begin{array}{l}2015-2020 \\
(6 \text { seasons })\end{array}$ & 122 & 57 & $3(2020)$ & 17 (2017) \\
\hline $\begin{array}{l}\text { Don Edwards San } \\
\text { Francisco Bay Na- } \\
\text { tional Wildlife Refuge, } \\
\text { Warm Springs Unit }\end{array}$ & $\begin{array}{l}2015-2020 \\
(6 \text { seasons })\end{array}$ & 36 & 15 & $0(2020)$ & $\begin{array}{c}4(2016 \&) \\
2017)\end{array}$ \\
\hline $\begin{array}{l}\text { Shoreline Regional } \\
\text { Wildlife Area in } \\
\text { Mountain View }\end{array}$ & $\begin{array}{c}1998-2020 \\
(23 \text { seasons })\end{array}$ & 250 & 125 & 1 (2019) & $12(2000)$ \\
\hline Total & & 1087 & 520 & & \\
\hline
\end{tabular}

feed all breeding Burrowing Owls in 2019. Results include the largest brood in over 22 years at one site and a 100\% nest-success rate at another site, which we had never observed prior to the supplemental-feeding study. Therefore, it is possible that supplemental feeding stimulated this double brooding.

Since 2012, we have banded each captured owl with a U.S. Geological Survey band on the right leg and pop-riveted an Acraft colored band bearing a unique alphanumeric code on the left leg, allowing us to distinguish resident, migratory, and supplemented/relocated owls. We surveyed the colony at Shoreline Regional Wildlife Area weekly, year round, collecting data on pair formation, longevity, breeding success, and patterns of movement within the colony and to additional sites in Santa Clara County and adjacent counties. At least monthly, we used binoculars, spotting scopes, or a long-lens camera to identify individuals by resighting the color and code on their Acraft bands. Motion-activated cameras, banding, and trapping with one-way-door bubble traps or bow nets during the breeding season allowed for identification of banded owls and recording of biometric data.

The successful pair that double brooded had been banded previously, allowing us to assess their breeding success over several years. The life history of this pair, female 5C (red-over-blue) and male 7R (red-over-blue), is as follows. In June 2014, we banded 7R as a fledgling at Shoreline from a brood of two young. From 2015 to 2018, remaining at Shoreline, he paired up with a different female each breeding season. In 2015 and 2017, no young were produced. In 2016, male 7R formed an incestuous relationship with his mother $6 \mathrm{U}$ (red-over-blue) and produced four young. From 2018 to 2020 , male $7 \mathrm{R}$ paired up with female 5C and successfully produced young for three consecutive seasons. In June 2018, we banded female 5C as an adult at Shoreline. The pair fledged six young in 2018 and six young in 2019, both years nesting in a complex of artificial burrows (\#245).

In 2020, 7R and 5C paired up for the third consecutive season, this time using a different artificial burrow complex (\#246), 68 meters from $\# 245$, first raising three young. Young were first observed on 18 May outside the entrance of \#246, where a motion-activated camera photographed three fledglings on 19 May (Figure 1). On 


\section{NOTES}

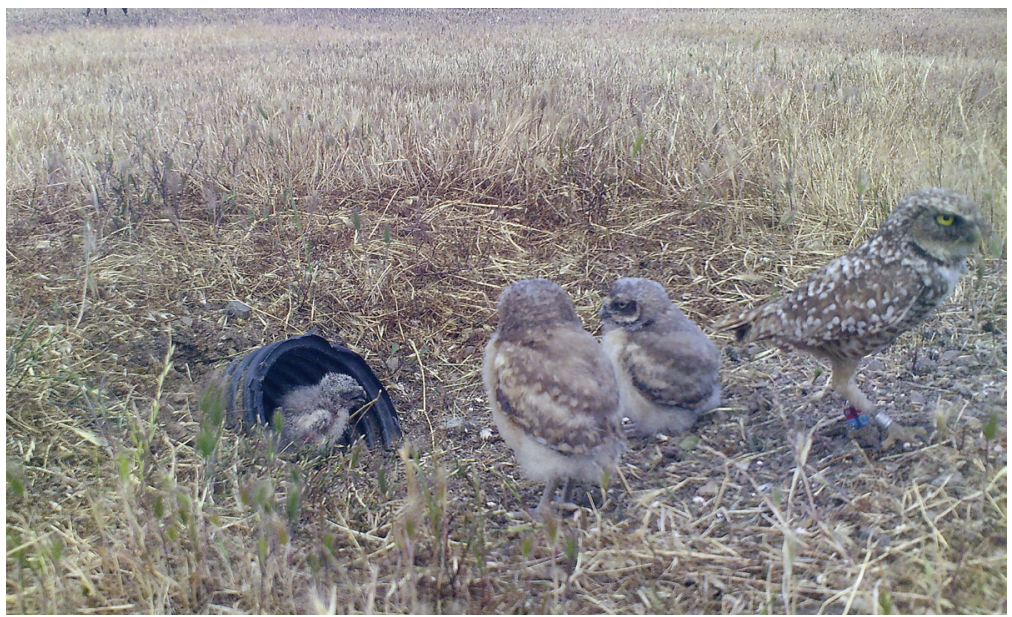

Figure 1. Female 5C with her three nestlings (14-22 days old) at nest \#246 on 19 May 2020.

26 May, we observed both adults at burrow location \#245 where they had nested during 2019. By 27 May, the adults had moved their young to burrow \#245. On 28 May, we banded two of the three fledglings from nest \#246 at location \#245.

On 3 June, we observed nest decoration, nesting material, and one adult at artificial burrow complex \#243, a distance of 55 meters from location \#245. Then, on 23 July, both banded adults and a single nestling were observed at nest \#243; the motion-activated camera photographed one young approximately 14 days old there on 24 July (Figure 2). On 3 August, we banded a 24-day-old fledgling. On 17

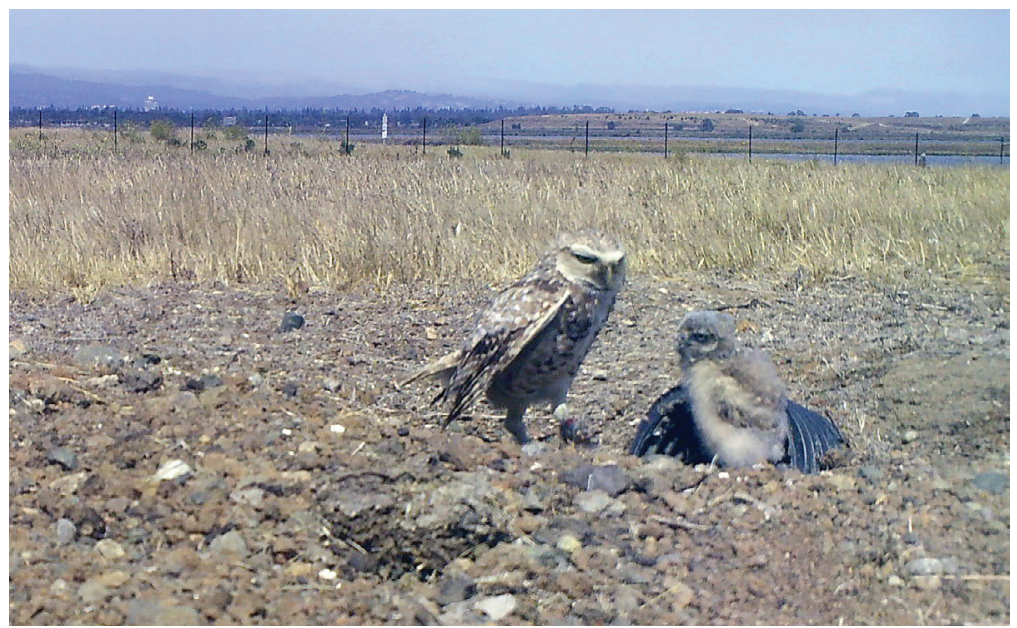

Figure 2. Second brood observed on 24 July 2020 with male $7 \mathrm{R}$ and unbanded nestling at nest \#243. 


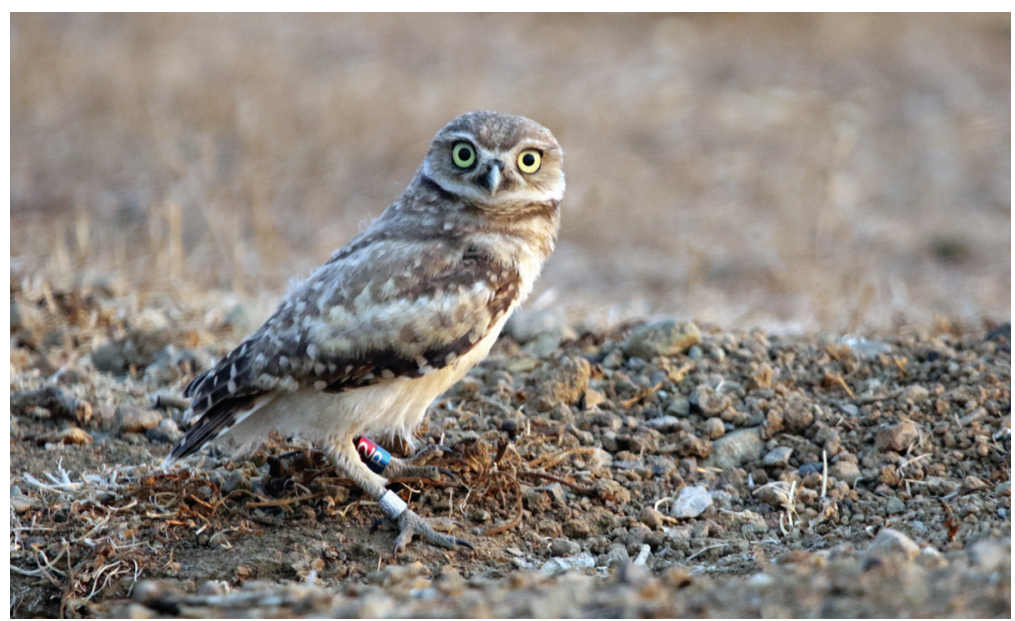

FIgURE 3. Fledgling 2P from second brood (nest \#243) identified at nest \#246 on 17 August 2020.

August, we observed that male 7R and the banded fledgling, approximately 38 days old, had relocated a distance of 116 meters and returned to nest \#246 (Figure 3). That only one young fledged in the second brood compared to three young in the first brood is a difference consistent with other studies of double brooding that have found the second brood tends to be smaller. Catlin and Rosenberg (2007) found a trend of decreasing clutch size with successive renesting attempts of Burrowing Owls in California.

Dietary limitations can impair the Burrowing Owl's reproductive success (Wellicome et al. 2013, Haley and Rosenberg 2013). On the basis of pellet analysis and remains of prey collected at burrows, including those at Shoreline Regional Wildlife Area, Trulio and Higgins (2012) found that 98\% of the diet of Burrowing Owls in the south San Francisco Bay area consisted of invertebrates, the Dermaptera being the order of insects most frequently recorded, representing $48.6 \%$ of all prey items by total number.

A diet low in rodents can depress the Burrowing Owl's reproductive success (Haley 2002, York et al. 2002, Rosenberg and Haley 2004). This situation, plus the Burrowing Owl usually catching only one prey item at a time, may be reducing the owls' reproductive success at Shoreline. Hence the purpose of the supplemental feeding study is to increase productivity. Preliminary results of the continuing supplemental-feeding study have been positive, with fed pairs producing twice as many young as unfed pairs. Haley (2002) also reported an increase in productivity of supplementally fed Burrowing Owls, and Wellicome (1992) reported supplementally fed females to lay more eggs and hatch more young than did those not supplementally fed.

We thank the Santa Clara Valley Habitat Agency for funding our Burrowing Owl monitoring and research projects and continued support of Burrowing Owl conservation. We also thank the city of Mountain View Community Services Department and Public Works Department, the U.S. Fish and Wildlife Service, and the California Department of Fish and Wildlife. 


\section{NOTES}

\section{LITERATURE CITED}

Catlin, D. H., and Rosenberg, D. K. 2007. Breeding dispersal and nesting behavior of Burrowing Owls following experimental nest predation. Am. Midland Nat. 159:1-7; https://doi.org/10.1674/0003-0031(2008)159[1:BDANBO]2.0.CO;2.

Gervais, J. A., and Rosenberg, D. K. 1999. Western Burrowing Owls in California produce second broods of chicks. Wilson Bull. 111:569-571.

Haley, K. L. 2002. The role of food limitation and predation on reproductive success of Burrowing Owls in southern California. Master's thesis, Ore. State Univ., Corvallis.

Haley, K. L., and Rosenberg, D. K. 2013. Influence of food limitation on reproductive performance of Burrowing Owls. J. Raptor Res. 47:365-376; https://doi. org/10.3356/JRR-12-00022.1.

Haug, E. A., Millsap, B. A., and Martell, M. S. 1993. Burrowing Owl (Speotyto cunicularia), in The Birds of North America (A. Poole and F. Gill, eds.), no. 61. Acad. Nat. Sci., Philadelphia.

Millsap, B. A., and Bear, C. 1990. Double brooding by Florida Burrowing Owls. Wilson Bull. 102:313-317.

Rosenberg, D. K., and Haley, K. L. 2004. The ecology of Burrowing Owls in the agroecosystems of the Imperial Valley, California. Studies Avian Biol. 27:120-135.

Thomsen, L. 1971. Behavior and ecology of Burrowing Owls on the Oakland municipal airport. Condor 73:177-192; https://doi.org/10.2307/1365838.

Trulio, L. A., and Higgins, P. 2012. The diet of Western Burrowing Owls in an urban landscape. W. N. Am. Nat. 72:348-356; https://doi.org/10.3398/064.072.0309.

Wedgewood, J. A. 1976. Burrowing Owls in south-central Saskatchewan. Blue Jay 34:26-44; https://doi.org/10.29173/bluejay4108.

Wellicome, T. I. 1992. Reproductive performance of Burrowing Owls: Effects of supplementary food. Abstract, Burrowing Owl Symposium. 1992 Raptor Res. Found. Annu. Meeting, Seattle.

Wellicome, T. I., Todd, L. D., Poulin, R. G., Holroyd, G. L., and Fisher, R. J. 2013. Comparing food limitation among three stages of nesting: Supplementation experiments with the Burrowing Owl. Ecol. Evol. 3:2684-2695; https://doi. org/10.1002/ece3.616.

York, M. M., Rosenberg, D. K., and Sturm, K. K. 2002. Diet and food-niche breadth of Burrowing Owls (Athene cunicularia) in the Imperial Valley, California. W. N. Am. Nat. 62:280-287. 